\title{
G. H. Mead: a system in a state of flux
}

\author{
FILIPE CARREIRA DA SILVA
}

\begin{abstract}
This article offers an original, intellectual portrait of G. H. Mead. My reassessment of Mead's thinking is founded, in methodological terms, upon a historically minded yet theoretically oriented strategy. Mead's system of thought is submitted to a historical reconstruction in order to grasp the evolution of his ideas over time, and to a thematic reconstruction organized around three major research areas or pillars: science, social psychology and politics. If one re-examines the entirety of Mead's published and unpublished writings from the point of view of contemporary social and political theory, one can see that his contributions transcend the field of social psychology. Mead's innovative insights on the communicative aspects of social life and individual conscience are yet to be fully explored by current social and political theorists. This is partly due to the fact that his was a system in a state of flux, ever escaping the final written form.
\end{abstract}

Key words democratic politics, experimental science, G. H. Mead, social psychology, sociological classics

\section{INTRODUCTION}

This article aims at showing that George Herbert Mead's social and political thought can be reconstructed as a building which evolved during the course of his career. To use an architectonic metaphor, it will be suggested that 
Mead's intellectual edifice is built upon three pillars. The first is the pillar of science that establishes the criterion for an internally democratic community of communication, a community that can be said to reflect the social implications of the 'method of intelligence', i.e. the scientific experimental method. The logical priority of the pillar of science within Mead's system of thought refers to the fact that the principles of the modern scientific method are applied in the resolution of specific problems in social psychology and democratic politics. The second is the pillar of social psychology that derives from the former pillar, given the scientific character that Mead claims for this discipline, and whose object is the social process of the formation of the human self. Finally, a theory of participative democracy and social reform, whose ethical implications must be submitted to scientific treatment, is the last pillar of an 'ambitiously projected but unfinished building', as Horace Thayer once put it (1968: 235).

It is my contention that the most important aspects of Mead's work are captured by these three topics. Of course, given the systematic nature of Mead's thought, some items do fall under the scope of more than one pillar, but nothing is excluded from at least one of them. What seems to result from this is a fundamental unity linking otherwise disparate writings, both in terms of the internal coherence of each pillar, and in terms of the systemic coherence of the whole. This unity, I argue, stems from the fact that the pillar of science takes logical precedence over the other pillars: it is from the perspective of a scientist that Mead analyses the social character of subjectivity and the 'social and moral order'. Furthermore, this theoretical system will be presented as a systematic effort to understand the societal shift towards modernity. Mead, contrary to what is widely assumed, not only developed an analysis of 'modern times' from the perspective of a social scientist concerned with the developmental logic of human consciousness, but studied the economic, political, social and moral consequences of the processes of industrialization, urban growth and expansion of the functions of the state as well. A central purpose of this article, then, is to bring out the systematic order of these fundamental elements of Mead's intellectual edifice. If there is coherence to his thought, I believe it will be reflected in the internal coherence of these three pillars as well as in their interconnectedness.

Three different analytical levels can be distinguished as far as my interpretation of Mead's thinking is concerned. At the metatheoretical level, I contend that history of theory and theory construction should be seen as different parts of the same endeavour. Pace Merton (1967), this article aims at showing that historicism can and should be reconciled with presentism. From a theoretical perspective, I suggest that the history of the reception of Mead's ideas in sociology can be best described as a narrative where 'Mead, the social psychologist' is the leading character, whereas the 'scientist' and the 'political thinker and activist' are hardly mentioned at all. This article is thus aimed 
at showing that such a narrative, however ingrained in the discipline's selfunderstanding, does not correspond to the truth. Finally, regarding my methodological strategy, I argue that historical or genetic reconstruction must be intertwined with a reconstruction based on topics or themes if one wishes to understand both the full scope and process of development of the object of study in question. In fact, a substantial part of the innovative character of my study of Mead lies in this particular methodological strategy. Of course, other Mead scholars have mobilized somewhat similar strategies. I am thinking of David L. Miller's path-breaking study (1973), Hans Joas's G. H. Mead: A Contemporary Re-examination of His Thought (1997[1985]), and the more recent books by Gary Alan Cook and Andrew Feffer (see Cook, 1993; Feffer, 1993). Nonetheless, as this article will show, the way I propose to reconcile a genetic reconstruction of Mead's ideas with a thematic one is distinctively different from any of them. ${ }^{1}$

\section{THE FIRST PILLAR: EXPERIMENTAL SCIENCE AND THE ACT}

My main aim in what follows is to analyse Mead's conception of science from the point of view of its evolution over time, beginning with the unpublished student notes from Mead's 1911 course on the 'Logic of the Social Sciences', and moving on to the period between the publication, in 1917, of 'Scientific Method and Individual Thinker' and Mead's last written work, the 1930 Carus Lectures published posthumously in The Philosophy of the Present (2002[1932]). The main topic of discussion will be Mead's theory of the act, a model of action with significant social-psychological and ethical implications.

Mead's conception of science is but a part of a more general socialtheoretical endeavour. In 1917, Mead ascertains this idea by arguing that the completion of the pragmatist programme of scientific activity is dependent on a sound explanation of the origin of human consciousness that dissolves the dichotomy between the psychical and the physical (see Mead, 1917: 206). Indeed, during the following decade, under the influence of the British philosopher Alfred North Whitehead, Mead writes a series of articles whose main purpose is to analyse the reconstructive process associated with the growth of scientific knowledge. Parenthetically, it must be noted that Mead's analysis of such a reconstructive process is a variation on a theme that had already caught his attention in the mid-1890s, when he accepted Dewey's invitation to join the Department of Philosophy at the University of Chicago. His later writings on the philosophy of science, around which my discussion in this section will revolve, are, from this point of view, the last and more articulated version of Mead's efforts to analyse the connection between human reflexivity and the reconstruction of experiential problems. 
An early version of Mead's treatment of this relationship is found in the aforementioned unpublished set of student notes dating from 1911. In this course, Mead presents a tri-dimensional analysis of the logic of the social sciences. He starts with their epistemological status, proceeds with a discussion of the social nature of rationality and concludes with an analysis of the ethical and political implications of his proposal. If there is one central motif in Mead's course, it is the idea of dialogue, a notion that is omnipresent throughout his analysis of human thought and consciousness. It is in linguistic communication that one can find the explanatory element needed for understanding the origin, process of development and full implications of rationality or, in Mead's pragmatist vocabulary, 'intelligence'. This is an explanation whose examples include, symptomatically, children's dialogues with their parents or the scientist's way of reasoning. The problem-solving nature of rational thought is seen as the socio-biological framework within which modern science must be understood.

This is summed up in a rather crucial passage from those student notes: 'This primitive attitude the logician calls the universe of discourse - it is rather the universe of intercourse.... In the forum of thought the individual himself appears as the person who presents the problem, then others appear as critics' (Mead, 1911). By calling 'universe of intercourse' what the logician calls the 'universe of discourse', Mead is trying to convey the idea that communication is the mechanism upon which human reasoning is founded. In particular, the problematizing attitude characteristic of modern experimental science is to be conceived as a logical extension of the emergence of the rational self.

For Mead, experimental science always operates with a mind that is social, for inferential thought includes the common reference of symbols in dialogue and thinking. That is, scientific rationality involves communication with ourselves and other individuals. What Mead is adducing here is the notion of 'sociality of science', a characteristic feature of Mead's conception of science in the 1920s. As Miller has already pointed out, the systematic nature of Mead's thinking comes to the fore when one considers the multiple applications of the principle of sociality (see Miller, 1973: 188-206). What I wish to discuss here is Mead's attempt to use his social-psychological view of human intelligence to explore the reconstructive process involved in scientific knowledge, i.e. the way both processes of thinking and science are explained in terms of the principle of sociality. This principle, contrary to what is suggested by Miller, should not be seen as the interpretative key to Mead's oeuvre. There is at least one good reason for this. It would be an unacceptable anachronism to read Mead's early work in the light of a conceptual category he developed in his later writings. The evolution of Mead's thinking cannot, therefore, be understood by reference to the principle of sociality. This principle, however, is very useful to clarify how certain aspects of his intellectual edifice are systematically connected. 
Briefly, Mead's attempt to connect his social conception of the self and his experimentalist conception of science is better understood by reference to the notion of sociality. The principle of sociality refers to a process of adjustment located in the present. As the process of adjustment unfolds, novel events (say, unexplained scientific data) are 'betwixt and between the old system and the new' (Mead, 2002[1932]: 47): during this period, they are unintelligible. Only when the adjustment is concluded do those events have a past and belong to a new system. In the case of the example suggested above, the adjustment occurs when a new scientific theory is able to explain the data: earlier exceptions can now be explained, along with all the data already explained by older theories. In this sense, Mead claims, the relation between the old and the new 'is a process of logical reconstruction by which out of exceptions the new law arises to replace a structure that has become inadequate'. Mead further notes that 'In both of these processes ... the individual functions in his full particularity, and yet in organic relationship with the society which is responsible for him' (Mead, 1917: 226-7). The old and the new world are thus social worlds: not only are the reflective thinking and the scientific method social undertakings, but 'the individual in whose experience both the problem and its solution must arise presupposes the community out of which he springs' (Mead, 1938: 60).

One can see here Mead connecting, in the most original way, his social conception of mind and thinking to his conception of experimental science. For Mead, mind is the ultimate example of the application of the principle of sociality. In a characteristically pragmatist fashion, Mead equates human intelligence with the resolution of action problems. When one's action is inhibited or there are conflicting tendencies to act, a problem arises. Its resolution demands a creative reconstruction of the situation: several lines of action must be considered by the individual in his mind before he decides which one seems the most adequate to solve the problem at hand. The process of adjustment, which the principle of sociality is supposed to explain, acquires in this case a particular form. The individual, as she reflects on the various possibilities of action, finds herself between two worlds: the old world (that she incorporates through the 'me' and the 'generalized other') and the new one, which emerges by means of the impulsive and unpredictable 'I'. Mead, in a clearly innovative way, thus suggests a link between reflective thinking and scientific knowledge. One sheds new light on the process nature of Mead's conception of the social self once one realizes that the established social order represented by the 'me' and the new order inaugurated by the 'I' affect each other in the most profound sense. The old world does not simply give way to the new world, in a continuous, linear fashion. Rather, Mead insists, the principle of sociality shows that the new 'me' must adjust to the old 'me', as the old has to adjust to the new. Similarly, the data explained by Newtonian physics must adjust to (i.e. must be explained by) 
Einstein's theories, even though the latter is of a more inclusive nature than the former (hence, scientific progress). For Mead, then, thinking is nothing short of 'the highest expression of sociality, because the organism only so passes from one attitude to another, by means of a phase which is a part of all these attitudes, but also comes back on itself in the process and responds to this phase' (Mead, 2002[1932]: 86).

This statement is a fine example of Mead's conception of science in the 1920 s. In this period, however, Mead's intellectual production on politics and morals suffered a slight decrease. In turn, his writings on a four-phased theory of action, on the theory of perception of the physical object that stems from it, and on his theory of time became more frequent and eventually came to assume a central position in his later thought. To begin with, Mead's dismissal of absolute idealism (see, for example, 2002[1932]: 171) is connected with the endorsement of the relativistic theories of Bergson and Whitehead. ${ }^{2}$ The existence of one single absolute perspective precludes the objectivity of individual perspectives, as well as evolution, novelty and creativity. On the contrary, Mead's social theory of human consciousness and Whitehead's relativistic philosophy share the same emphasis on the 'objectivity of perspectives' (1938: 114). What Mead wishes to select from the latter's proposal is its 'conception of nature as an organization of perspectives, which are there in nature' (2002[1932]: 173). Individual perspectives emerge from a social perspective which, in turn, transcends the mere collection of individual perspectives. But how can one secure the objectivity of individual perspectives? In Mead's view, the answer to this question lies in a pragmatic test. An individual perspective, understood as an organization of events, is considered to be objective or real if it leads to the consummation of an act that was previously inhibited.

At this point, it is necessary to bear in mind that Mead conceives of the act as comprehending four stages. First, there is an impulse, in the sense of a physiological predisposition of the organism to respond to a given stimulus; second, the organism perceives either an object or a segment of the surrounding environment; ${ }^{3}$ third, the organism manipulates the perceived object, either physically (e.g. an apple) or intellectually (e.g. a past event); fourth, the organism attributes a certain value to the object in question thereby consummating the act. ${ }^{4}$ Mead's theory of the act has been recently re-examined by Alex Gillespie (2005) in a refreshing and provocative way. Gillespie's claim is that the kernel of Mead's contribution to contemporary debates on the origins of consciousness is 'a social interaction that has become an institution, with established positions ... which are stable over time' (2005: 27). This social interaction is designated as a 'social act': 'The social act, and not the act, provides a means to escape Cartesian solipsism', Gillespie argues (2005: 34). Beyond any doubt, we have here one of the most innovative interpretations of Mead's work to appear in the last decade or so. My acknowledgement of 
this fact, however, should not be seen as an unreserved endorsement of Gillespie's thesis.

My chief reservation regarding Gillespie's interpretation concerns his inability to adequately appreciate the intersubjective and dialogical nature of Mead's conception of the act. ${ }^{5}$ Gillespie claims that Mead's central contribution is the social act because Mead's conception of the act 'has little room for the other' (2005: 34). In my view, to suggest that Mead's theory of the act is individualistic (i.e. is based upon a self-object dyadic relation), and that one has to focus on his notion of 'social act' to find a truly intersubjective contribution, amounts to failing to appreciate the actual nature and extent of Mead's version of intersubjectivism. This is particularly clear when one considers the way Gillespie contrasts the act (portrayed as individualistic) and the social act (the sole source of intersubjectivity). Such a dichotomy is totally strange to Mead's thinking. It conveys the (wrong) idea that Mead made a rigid separation between the act and the social act, the former being a remnant of Dewey's influence and the latter his great contribution. On the contrary, for Mead, the intersubjective nature of social life lies as much at the level of interpersonal relations (the subject-subject relation mentioned by Gillespie), as it does at the level of individual minds (the subject-object relation mistakenly considered by Gillespie to be non-intersubjectivist). Mead's chief contribution to contemporary debates on intersubjectivism is not the social act as Gillespie suggests (which is but a specific category of acts that involve the cooperation of more than one individual), but a conception of action and rationality that encompasses the whole range of human experience, from the individual four-phased act to large-scale social interactions. Moreover, I would like to emphasize that Mead's starting point is not the individual act, performed by a solitary rational being, but the social interaction through which individual selves eventually emerge. Process, evolution and emergence are the cornerstones of Mead's intersubjectivist model: from the individual act to complex social acts, the rationale of Mead's analysis is, contrary to what is suggested by Gillespie, exactly the same.

The problem with Gillespie's line of thought is that it excludes 'objects' from his analysis. It is a purely subject-subject relation that Gillespie tries to find in Mead. Mead, however, always rejected such a culturalist understanding of mind and consciousness. My claim is that Mead's chief contribution for the overcoming of Descartes' solipsistic model is a theory of the act according to which social actors engage with the world of which they are part and parcel, including other individuals and themselves, in such a way that they are able to control their conduct. Among his brilliant insights lies the idea that as the object controls the act, social objects control the social act. Gillespie, like anyone whose analysis is primarily culturalist, fails to grasp this important claim. At the root of Mead's contribution to the overcoming of the Cartesian paradigm is the insight that the act, with its four 
distinguishable phases, can be conceived only within a social act: the meaning of the act of an individual, as Mead always emphasized, lies in a 'threefold relationship of gesture to adjustive response and to the resultant of the given social act' (Mead, 1997[1934]: 80). In other words, the meaning of an individual action is found to be implicit in the structure of the social act. One cannot thus claim that the only intersubjective element of Mead's social theory is the 'social act'; the social act is itself composed of symbolically mediated acts, whose intersubjective character should not be underestimated.

\section{THE SECOND PILLAR: SOCIAL PSYCHOLOGY}

My aim in the present section is to demonstrate the logical priority of the pillar of science in relation to the pillar of social psychology. In other words, I shall discuss the point of view from which Mead 'attacks the problem of consciousness'. I contend that Mead examines this problem through the lens of a research scientist. The scientific attitude bears a strong resemblance to the perspective of a 'generalized other'. In turn, the latter standpoint is very similar to the attitude of a moral agent able to make critical moral judgements. In this section, I shall start by indicating the similarities between these standpoints. As will be seen, all three perspectives share an orientation towards abstraction, impersonality and objectivity. It is possible, as I shall next seek to show, to find behind such a 'convergence of perspectives' two fundamental elements of Mead's system of thought: his conception of knowledge and his model of action. Finally, this will bring me back to the guiding theme of the section, Mead's project of a 'scientific social psychology' (1994: 379 ) in the context of his conception of the relation between the natural and social sciences. As in the other two pillars, my methodological strategy here involves both a genetic and a thematic reconstruction of Mead's ideas. When applied to the case of social psychology, this strategy allows us to see that the abstract and impersonal perspective associated with the 'generalized other' is a concrete instance of how the three different problem-areas to which Mead devoted his career all come together.

Mead introduces the notion of the 'generalized other' as an essential condition for the full development of the human self. ${ }^{6}$ This concept refers to a set of social attitudes that are internalized by the self. How does Mead explain this process of internalization of social norms? Rejecting the traditional Cartesian model of the self as a passive recipient of external social rules (thus replicating, at the social-psychological level, the dichotomy between a subjective inner world and an objective external reality), Mead suggests a model according to which the self is an active interpreter of social attitudes. The concept of the 'generalized other' helps Mead explain how, during the game stage of the process of childhood development, children 
learn to monitor their conduct according to the perspective of everyone else. While playing at games, children take the role not of a single individual other (which they do while playing a specific character as in Mead's famous example of the 'Indian'), but of each and every other team mate - such a set of organized attitudes is the 'generalized other'. Of course, the game stage is but the prelude to social life. As children grow, Mead argues, they gradually acquire the ability to import the attitudes of the social group into their own selves. For Mead, the self takes part in social life not by playing pre-given social roles, but by interpreting and reformulating in its mind the attitudes that are common to the group.

How exactly does the attitude of the 'generalized other' relate to the socialpsychological mechanism of taking the role or attitude of the other? The best answer to this question is found in an undated and posthumously published paper, 'Consciousness, Mind, the Self, and Scientific Objects' (Mead, 1982). To begin with, Mead argues, self-consciousness is attained when the self acquires the ability to become an object to himself: 'Mind is that part of experience in which the individual becomes an object to himself in the presentation of possible lines of conduct' (Mead, 1982: 177). Associated with this self-objectifying ability, Mead points to the presence of certain affinities in the organisms of the individuals engaged in the social act - for instance, the social stimulus that is the vocal gesture must be heard and understood in a similar way by the individuals in question (see also Mead, 1925: 270). He then calls our attention to the set of 'common attitudes' at the disposal of the individuals: each and every one of us is able to take the attitude of everyone else - social life can thus best be described as a 'generalized environment' inhabited by 'generalized organisms'. Mead concludes:

The effect of taking the role of anyone is to eliminate the peculiarity of the environment of any one individual and to substitute for any concrete individual an abstraction - a generalized individual, the thinker. (Mead, 1982: 178)

In short, the 'generalized other' provides Mead with a social-psychological explanation for (1) abstract thinking, (2) social control as rational selfcriticism, and (3) self-consciousness. As to abstract thinking, Mead identifies it with communication with oneself when one speaks in the voice of the community to which one belongs. When, for instance, we offer a price for a car, we are taking all the roles from the producer to the sales manager. In so doing, we may, for instance, say the car is too costly since we can put ourselves in the various stages of its production, commercialization and utilization. In this way we respond to the entire community - this response thus acquires a universal character. In referring to the ability of exerting rational self-criticism by role-taking the 'generalized other', Mead points to the incorporation of social norms and expectations through the 'me'. In this 
sense, social control is as much a source of social regulation of individual behaviour as it is a source of individuality (see Mead, 1997[1934]: 255). Finally, Mead's intersubjective explanation of the emergence of self-consciousness is closely related to our capacity of taking the attitude of the 'generalized other'. Social life requires that the individual takes up a variety of social roles and common attitudes. When the individual addresses himself in the attitude of the group, he becomes a generalized other. Since 'the others and the self arise in the social act together', he becomes a 'definite self over against the social whole to which he belongs' (Mead, 1926: 81, 80).

As this last passage indicates, the attitude of the 'generalized other' can be discussed also from the vantage point of Mead's theory of the act. As he explains in 'The Genesis of the Self and Social Control' (1925), whereas vocal gestures belong historically to the beginning of the act, having provided in phylogenetic terms the medium of social organization in human society, the 'generalized other', which enables us to 'attain to the levels of abstract thinking, and that impersonality, that so-called objectivity that we cherish' (1925: 272), is located in the later phase of manipulation. The 'generalized other' is still connected to another phase of the act, namely the stage of consummation. As Mead contends in 'The Objective Reality of Perspectives' (1926), the common perspective associated with the generalized other 'exists in the organisms of all the members of the community, because the physiological differentiation of human forms belongs largely to the consummatory phase of the act' (Mead, 1926: 80).

As will be shown in the next section, the critical vantage point from which one can criticize the existing moral order is precisely the standpoint of a 'generalized other'. The example of a child in a room mapping the environment, crawling about, perceiving a given object at a distance, seeing it at successive moments in time until she eventually grabs it, is what Mead has in mind when he equates knowledge with the process of coordination of perspectives (see 1938: 134). As one can see, the phase of the act in which the coordination of perspectives is achieved is that of manipulation. Mead, however, is very keen on rejecting the identification of the percept with the object of knowledge. Rather, Mead identifies knowledge with the solution of problems human beings face whenever they act, either in scientific research, in social situations, or in moral and political contexts. From his model of action, one can draw significant conclusions concerning which kind of knowledge can be found in each of these contexts of action. In moral situations, cognition is correlated to the phase of consummation: the moral agent knows the value of an object as a result of the practical interaction between him or her and the object of perception. In social situations, the objectivity attained augments insofar as cognition is related to perception from a distance of secondary qualities (such as sounds). Such is the case of two individuals in dialogue with each other. The most objective knowledge, however, 
occurs in the context of scientific research. The interaction between subject and object in this situation is based on the cognition of primary qualities (such as mass) through the manipulation of objects (1938: 104).

I am now in a position to draw a parallel between the perspective of the scientist and the standpoint of a 'generalized other'. The textual basis that will be summoned in support of this assertion is found in two of Mead's articles: 'The Objective Reality of Perspectives', published in The Philosopby of the Present, and 'Perception and the Spatiotemporal', included in The Philosophy of the Act. In the first essay, Mead discusses the conception of a set of events as the organization of different perspectives of these events, from the point of view of a scientific social psychology. The objective data of such a scientific discipline consist in 'those experiences of the individuals in which they take the attitude of the community [i.e. the generalized other]'; by making use of these data, the critical social scientist is 'only replacing the narrower social perspectives of other communities by that of a more highly organized and hence more universal community' (2002[1932]: 175). Seen in this light, the experimental method is the technique by which the individual perspective becomes the perspective of the most universal community, that of the 'logical universe of discourse'.

In the second essay, Mead provides us with a description of how scientists apply this technique. As he explains, in the case of a fig-tree, it is only from the point of view of the scientist that fig-trees reach their fruitage through the action of the wasps. The two stories of the fig-tree (fertilization of the flower) and of the wasps (digestion of the honey) intersect when seen from the standpoint of the scientist who introduces wasps to fertilize fig-tree flowers. In a sense, then, the scientific perspective 'includes the perspectives of both' the fig-tree and the wasps (1938: 184). This ability of the scientist to reach a standpoint which includes the perspectives of the various objects of knowledge is but the systematic development of the human ability to assume the attitude of the 'generalized other', as reconstructed by social psychology. What Mead is suggesting, after all, is that one can draw a parallel between the scientist, who takes a perspective able to unify an object of knowledge, and the attitude of a 'generalized other', which allows the emergence of a unified self.

Mead's conception of the relation between the natural and social sciences helps one to understand the way in which social psychology is supposed to be a scientific endeavour. In the social and natural sciences alike, given the experimental and problem-solving nature of their activity (see, for example, 1906: 391), scientists are interested in particulars insofar as they emerge as exceptions to universals. The solution of the problem brings with it the disappearance of particular instances in the 'universality of the law' (1938: 634). In the case of the physical sciences, the scientist frees her or his perceptions from the idiosyncrasies and perspectives of particular observers through the discovery of the 'uniformities which hold for all observers and thinkers' 
(1938: 22). Similarly, in a scientific social psychology, the standpoint to be adopted should be one that lies in the intersection of all differing perspectives on the object so that it can disclose the self's uniformities that can serve as data for scientific experimentation, while at the same time retaining their particular content. Psychical events become scientific data only when they correspond to definite conditions of objective experience.

This attempt to reconcile the universal character of social psychology's data and the particular nature of the human mind is revealed when Mead discusses the relation between the attitude of a 'generalized other' and social control. If a science of the self presupposes such an abstract, impersonal and objective perspective so that the typical features of the human self are identified, does this mean that there is no space for individuality in Mead's scientific social psychology? Very much on the contrary, by identifying social control with the self-critical attitude of the individual who adopts the attitude of a 'generalized other', Mead argues, in his 1928 lectures on social psychology, that social control is 'actually constitutive of and inextricably associated with that individuality; for the individual is what he is, as a conscious and individual personality, just in as far as he is a member of society' (1997[1934]: 255).

\section{THE THIRD PILLAR: COMMUNICATIVE ETHICS AND DELIBERATIVE DEMOCRACY}

Among the first written documents in which one can find stated Mead's favouring of a scientific approach to the solution of political problems is the 1900 article 'Suggestions Towards a Theory of the Philosophical Disciplines'. In this important paper, Mead suggests that reflective thought can reconstruct a problematic situation in two distinct ways. One can approach a moral problem either by deductively reaffirming old meanings as they apply to the problem in question, or by inductively searching for new meanings: for instance, poverty can be conceived of either as a natural feature of human societies or as a social problem requiring solution. Mead considers this latter approach to be superior since it treats moral problems as occasions for moral growth, and not as 'chronic and destructive' conflicts (1900: 15). Furthermore, such an inductive method of moral reconstruction bears a strong resemblance to the experimental method used by the research scientist: the moral agent has to do justice to all the relevant values in the problematic situation, just as the scientist has to take into account all the relevant facts in order to produce a working hypothesis. Some years later, Mead restates this idea in 'The Philosophical Basis of Ethics' (1908). In this article, however, Mead no longer speaks of inductive and deductive moral methods, but of 'abstract external valuation' and 'concrete valuation' (1908: 322). Notwithstanding this terminological modification, Mead's favoured approach to 
morals continues to reject any appeal to a transcendent fixed moral order. Mead identifies this latter approach with the attitude of the 'pulpit', suggesting that one should assume instead the attitude of the 'scientific investigator' (1908: 321). Whereas abstract external valuations are made in reference to a fixed model of previously existing conduct, concrete valuations have the advantage of confronting the moral agent with a dialectic process of moral reconstruction, very much in the spirit of experimental science. Comparing an engineer's task of constructing a railroad with a moral agent's need to solve a moral problem, Mead asserts that moral advance can be secured only if the moral agent is able to experimentally evaluate and eventually abandon or transform old moral values (1908: 320). Moral growth, like scientific growth, is a creative intellectual process.

In the 1913 article 'The Social Self', Mead connects for the first time this reflection on morals to his insights on social psychology. Such a connection is made taking into consideration his conception of science as a problem-solving procedure. Comparing this text with Mead's previous writings, the major difference lies in the 'essentially social character of the ethical end' (1913: 378) and of the process by which moral problems are supposed to be resolved. Returning to the example of poverty, the intelligent resolution of this problem is equated with the good of the community as a whole. Mead now criticizes as 'selfishness' what earlier he called 'deductive' and 'external valuation' methods of moral reconstruction. His favoured way of solving moral problems and securing moral growth is still an approach that does justice to all the values at stake. By resorting to reflective analysis, the moral problematic situation can be reconstructed in such a way that new and enlarged selves may emerge. What science teaches us, Mead claims, is that out of a moral problem a new self can emerge, a self whose interests are much more in accordance with the community's interests than those of the old self. Problems involving conflicting moral values should, then, be seen as instances of moral reconstruction and growth. In this respect, the logic of moral and scientific reconstruction is identical. There is, however, one fundamental difference between the scientific and the moral solution of a problem. Whereas scientific problems concern interests that do not affect the human self, moral problems deal with 'concrete personal interests, in which the whole self is reconstructed in its relation to the other selves whose relations are essential to its psychology' (1913: 379). What 'The Social Self' introduces is a psychological treatment of moral issues in the light of the method of intelligence. In this article, one can see how each pillar contributes to the workings of Mead's system of thinking: science gives the method, social psychology the objective explanation of human subjectivity, and morals and politics the objective solution for the problems of the 'moral or social order' of modern industrial societies.

In the 1923 article 'Scientific Method and the Moral Sciences', Mead develops what is arguably his best articulated account of a 'psychology of 
ethics'. Mead's starting assertion identifies the realm of morals with social life since 'morality has to do with the relations of intelligent beings with each other' and 'this determined moral or social order is a world as it should be and will' (1923: 230). There is, though, a dichotomy between two attitudes towards the social or moral order in which human beings develop their lives. On the one hand, there is the religious or teleological attitude taken by those for whom ethical ends are given in advance and who regulate their social and moral conduct accordingly. On the other hand, there is the scientific or mechanical attitude taken by those who distinguish a moral order that is anticipated from a natural order that is known a posteriori (1923: 231-2). Mead highlights the fact that humanity has been very successful in applying the scientific method to the natural order while leaving the moral order out of the field of scientific analysis. Among the most negative consequences of this situation, Mead adduces the examples of the First World War, a conflict triggered by the particularistic and narrow nature of the ends in dispute, and of municipal politics, where policy-making hardly makes any use of scientific knowledge. Mead's position is unequivocal: 'It would be a mistake to assume that scientific method is applicable only in the fashioning and selection of means, and may not be used where the problem involves conflicting social ends or values' (1923: 235).

Such a categorical statement seems, in the light of contemporary moral philosophy, difficult to sustain. Contrary to the faith in scientific progress characteristic of most members of Mead's generation, today's reflection on morals tries at best to attain logically plausible arguments, avoiding any claims of being able to achieve law-like rules or maxims. There are, however, contemporary attempts to construct scientific moral-philosophical theories, even if this scientific character is carefully distinguished from the knowledge produced by the natural sciences. ${ }^{7}$ I would nevertheless like to emphasize that Mead's scientific approach to moral and social problems itself embodies an ethical ideal, an ideal of an impartial resolution of moral problems. Such an impartiality is inspired by the attitude of the research scientist.

The ultimate goal of a science of politics and morals is the resolution of concrete ethical problems. Exactly how this science is to be intertwined with a scientific theory of the psyche was something Mead felt the need to explain to his students in his lectures on social psychology. In fact, the social theoretical basis of Mead's moral and political thought can be grasped in scattered remarks throughout Mind, Self, and Society. In this book, Mead speaks of a further attitude in which the social-psychological mechanism of 'taking the role of the other' enables the individual to 'enter into the attitudes of the group and to mediate between them by making his own experience universal, so that others can enter into this form of communication through him' (1938: 257). Mead is here referring to the statesman, whose ideal stance is as universal as the community in which he lives. Democratic politics, 'this great co-operative 
community process which is going on' (1938: 188), depends on the level of participation and communicative interaction between the citizens. The statesman is able to conduct social reform only insofar as he is able to adopt the attitude of the 'generalized other'. And it is this capacity for taking the generalized attitudes of their social group that provides politicians with a 'universe of discourse' in terms of which they can address political problems in an impartial manner (1938: 89-90). Just as a critical moral agent is able to make use of abstract thought to formulate a hypothesis of an alternative moral order, a statesman is able to resort to the method of intelligence to reconstruct social and political problems intelligently. Critical moral and political reflection depends on a standpoint from which the 'social or moral order' may be judged. Such is the perspective of abstraction, impersonality and objectivity that distinguishes science from other human activities.

Mead's ethics is, then, a scientific attempt to reflect on the practical procedure of solving moral problems, a procedure which lays emphasis on the creativeness of the reconstructive aspect of this problem-solving task. A moral agent is able to criticize his own cultural horizon as long as he is able to appeal to an 'ideal world that lays claim upon him', an ideal world, however, that 'grows out of this world and its undeniable implications' (Mead, 1930: 145). ${ }^{8}$ Mead's definition of such an ideal world that 'grows out of this world' is unmistakably drawn from his understanding of science and social psychology - 'the individual shall take into account all the values which have been abstracted from their customary settings by the conflict and fashion his reconstruction in recognition of them all' (Mead, 1930: 146). The radical democratic implication of this moral philosophical argument is that scientific knowledge should be disseminated throughout all social layers so that every individual citizen can have access, by means of his or her intelligence, to the results of science. The rational communicative basis of Mead's democratic ideal is clear. All social and political institutions should be permeable to the communicative fluxes coming from an informed citizenry; the necessary and sufficient condition for this to happen is the definition of the rational procedure for attaining agreements through mutual understanding. Science and democracy, sustained by universal education and intelligent social reform, are, in a clear pragmatist fashion, the sources of inspiration for Mead's proposed solutions for the problems of modern industrial society.

Once again, I would like to stress the importance of the unpublished manuscripts held at the Mead Papers Archive. First, Mead's rejection of technocratic solutions for the problems of increasingly complex and differentiated societies goes hand in hand with his faith in the capacities of an informed public opinion. 'Government by experts', as Mead argues in an unpublished paper on the labour movement during the First World War, is founded upon a fundamental fallacy: 'The fallacy is the old one that out of mere interest in good government an autocratic power above can govern in the interest of all. 
On the contrary, the power, prestige, and wealth of the upper caste will inevitably subordinate to themselves the good of the whole community' (Mead, 1917-18: 12-13). Second, Mead's understanding of citizenship, only treated in passing in his published articles and posthumously published books, is the theme of an important unpublished essay. ${ }^{9}$ Probably written during the First World War, this essay shows how entangled Mead's various interests are. For Mead, citizenship is the political correlate of the social nature of the human self. A communicative theory of society, if it wishes to study the political realm, has to analyse the political implications of membership of a community. Mead draws a parallel between the individual's membership of a social group and of a political community, with the purpose of emphasizing the structural and unconscious nature of these allegiances. His point is that our institutions, such as the family, the school, or the court of justice, change and evolve in ways we are not conscious of, except when they are put into question. In moments of conflict, Mead asserts, the fundamental social values embodied in these institutions are brought to consciousness. In those moments, individuals have to resort to the method of science in order to reconstruct the problematic situation. In his own words,

If we could attack the institution by way of continual reconstruction we would have as real an opportunity of feeling its import as we have of the value of meeting a friend when we reconstruct our program giving up this, that or the other privilege to compass this opportunity. We get hardly more immediate meaning out of the constant process of the evolution of social institutions than we do out of the processes of dialectical changes which take place in our mouths ... as great laws of speech. (n.d.: 10-11)

This last passage reveals Mead's willingness to connect political and moral theory to an analysis of the human language by means of a communicative theory of society and of the human self. From this perspective, Mead's political endorsement of radical democratic political solutions of a deliberative kind is of particular relevance. Of course, this is not to say that Mead actually developed a complete account of a deliberative model of democracy. Rather, what I wish to suggest is that his political writings comprise a number of assumptions that escape the traditional dichotomy that separates liberal from republican models of democracy. ${ }^{10}$ Though less articulated than Dewey's, Mead's pragmatist political thought is, nonetheless, sustained by a conception of science and a theory of social psychology that is unparalleled among his contemporaries. The dialogical and cognitivist nature of Mead's system of thinking is the key that unlocks the various doors of his intellectual edifice. From a conception of science as a cooperative effort for the mobilization of human intelligence in the resolution of research problems through the definition of a working hypothesis, to a social psychology which aims at exposing 
the social nature of human consciousness, and from this to a moral and political theory that draws on these two pillars in order to study the 'social and moral order' of modern industrial societies, the same regulatory ideal is suggested - that of a rational exchange of arguments having in mind all the relevant facts in order to reach an agreement.

\section{CONCLUSIONS}

In this article, I introduced the architectonic metaphor of an intellectual building sustained upon three pillars, each one related to the other two in a systematic fashion, with the purpose of showing how misleading it can be to take Mind, Self, and Society as Mead's magnum opus. Very much to the contrary, as I have tried to demonstrate, that particular set of lecture transcripts provides access to only a fragment of Mead's intellectual production. Mead's enterprise was an ambitious one, both in scope and complexity. From a theory of human phylogenesis and ontogenesis to an analysis of language as a medium of communication and social coordination, from his writings on the history of science to his theory of the act and his philosophy of the present, from his radical theory of democracy to his ethical theory oriented to the resolution of moral problems, Mead's oenvre emerges, in the light of my interpretation, as a classical account of American social and political theory. I have also maintained that the relation between current practitioners and the classic figures of their disciplines should be of a dialogical nature. This is why I believe it necessary to reconstruct in a historically minded fashion the past contributions of the social and human sciences if meaningful dialogue is to take place. By offering an interpretation of his system of thought based on the largest amount of textual evidence possible, my aim was not so much to point to possible ways Mead's system of thinking can benefit theory construction in the present, as to provide a re-examination of his social and political thinking that is, in itself, a theoretical resource for contemporary social and political theorists. Contrary to the generality of the commentators, who favour either chronological reconstructions of Mead's ideas or purely thematic ones, I have tried to show the advantages of reconciling a historical reconstruction with a reconstruction based on topics. To some extent, this goal is consonant with my aim of contributing to the dialogical interplay between competing social and political theoretical proposals. Mutual understanding between contemporary theoretical models can be improved, even if only marginally, if the basis of our dialogue is not a set of concepts reconstructed according to each theorist's present needs, but a conceptual apparatus reconstructed with the purpose of attaining historical accuracy. Seen in this light, my central assertion that Mead's system of thinking exists in a state of flux seems to gain an increased significance. 
Take the psychological mechanism of 'taking the role of the other'. This crucial Meadian concept can be seen operating in the attitude of the research scientist, in the attitude of the social actor (both from a phylogenetic and an ontogenetic viewpoint), and in the attitude of the citizen. On the other hand, there are different kinds of social environments within which the human self develops its activities by meeting problems and adapting to changing circumstances: the scientific community, the social group and the political community. These pillars are linked in other aspects too. Given the priority of the scientific pillar, the two others can be seen as scientific approaches to specific problems, either the problem of the social origins of the individual self, or the problem of the moral and political organization of modern industrial societies. The relative importance of the second pillar is reflected in a distinctively social-psychological approach that is mobilized to analyse, for instance, the political phenomena. Finally, one can find a categorical conception of democracy in all layers of Mead's writings. The notion of an egalitarian, impartial, open to participation and discussion social order pervades all aspects of his system of thought, from the inner forum of conversation to international relations between nation-states.

The perspectives to which I am alluding reflect the eclectic character of Mead's thinking insofar as they are located in distinct problem-areas. The relative autonomy of the perspectives of the research scientist, of the social actor, and of the moral agent, however, should not mislead us. They are all phases of Mead's scientific enterprise, whose similarity demonstrates the systematic nature of his thinking. One can perhaps speak of 'convergence of perspectives': each pillar of Mead's system of thought comprehends a certain perspective that is structurally similar to the remaining two; they converge in their common orientation towards abstraction, impersonality and objectivity. Science's practice of rational exchange of arguments between equals, in which all facts must be taken into consideration and subjected to empirical testing, and in which every solution is inescapably provisional, is the model upon which Mead draws to conceive of democracy. The cognitive and linguistic nature of Mead's conception of democratic politics provides compelling evidence in support of this thesis. If 'science and democracy' is a common theme amongst classical pragmatists, it is to Mead that we owe the only communicative social theory that systematically connects science's problem-solving nature to democracy's deliberative character by means of social psychology that establishes the social nature of the human self. Such is one of Mead's seminal contributions to contemporary social and political theory. 


\section{NOTES}

With sincere appreciation I thank Donald N. Levine, Mónica Brito Vieira, Patrick Baert, Darin Weinberg, and William Outhwaite for thoughtful and challenging comments on, or conversations about, earlier versions of this paper, as well as for inspiration and support. I am also grateful to the three anonymous reviewers for their criticisms and comments on this article.

1 For a critical analysis of the work of these Mead scholars, see Silva (2007), especially ch. 8.

2 For Mead's criticism of Hegel, see, for example, Mead (1938: 505); for Mead's endorsement of Whitehead's relativist 'philosophy of organism', see, for example, Mead (1938: 280).

3 Mead describes perception as the 'relation between a highly developed physiological organism and an object, or an environment in which selection emphasizes certain elements' (1938: 8).

4 'Within the field of consummation all the adjectives of value obtain immediately. There objects are possessed, are good, bad, and indifferent, beautiful or ugly, and lovely or noxious' (1938: 25).

5 As I have argued elsewhere, the intersubjectivism that allows Mead to supersede Cartesian atomism without falling into the excesses of sociologism is founded upon a conception of the act that is irreducibly dialogical (see Silva, 2007).

6 One of the best recent analyses of Mead's concept of the 'generalized other' is Dodds, Lawrence and Valsiner (1997).

7 One case in point is Jürgen Habermas's discourse ethics, a programme of research developed with Karl-Otto Apel since the mid-1970s.

8 Mead's discussion of religious or intellectual geniuses, such as Jesus or Socrates, in his 1928 lectures on advanced social psychology is based upon this very same argument. See Mead (1997[1934]: 217).

9 I refer to Mead's unpublished and undated paper 'How Can a Sense of Citizenship Be Secured?'

10 See, for example, Habermas (1996).

\section{BIBLIOGRAPHY}

Cook, G. A. (1993) George Herbert Mead. The Making of a Social Pragmatist. Urbana, IL: University of Illinois Press.

Dewey, J. (1927[1984]) The Public and Its Problems, in J. A. Boydston (ed.) Jobn Dewey: The Later Works, vol. 2, 1925-1927. Carbondale, IL: Southern Illinois University Press.

Dodds, A., Lawrence, J. and Valsiner, J. (1997) 'The Personal and the Social: Mead's Theory of the "Generalized Other", Theory and Psychology 7: 483-503.

Feffer, A. (1993) The Chicago Pragmatists and American Progressivism. Ithaca, NY: Cornell University Press. 
Gillespie, A. (2005) 'G. H. Mead: Theorist of the Social Act', Journal for the Theory of Social Behaviour 35(1): 19-39.

Habermas, J. (1996) 'Three Normative Models of Democracy', in S. Benhabib (ed.) Democracy and Difference: Contesting the Boundaries of the Political. Princeton, NJ: Princeton University Press.

Joas, H. (1997[1985]) G. H. Mead: A Contemporary Re-examination of his Thought. Cambridge, MA: MIT Press.

Mead, G. H. (1900) 'Suggestions Towards a Theory of the Philosophical Disciplines', Philosophical Review 9: 1-17.

Mead, G. H. (1906) 'The Teaching of Science in College', Science 24: 390-7.

Mead, G. H. (1908) 'The Philosophical Basis of Ethics', International Journal of Ethics 18: 311-23.

Mead, G. H. (1911) 'Logic of the Social Sciences', unpublished typescript of student notes by Juliet Hammond, Mead Papers Archive, box 8, folder 8, 94 pp., Department of Special Collections, Regenstein Library, University of Chicago.

Mead, G. H. (1913) 'The Social Self', Journal of Philosophy, Psychology and Scientific Methods 10: 374-80.

Mead, G. H. (1915) 'Social Psychology', unpublished manuscript of student notes by Irene Tufts Mead, spring quarter, Mead Papers Archive, Addenda, box 4, folder 11, 59 pp., Department of Special Collections, Regenstein Library, University of Chicago.

Mead, G. H. (1917) 'Scientific Method and Individual Thinker', in J. Dewey et al. (eds) Creative Intelligence: Essays in the Pragmatic Attitude. New York: Henry Holt.

Mead, G. H. (1917-18) 'On Labor's Interests in World War I' (unpublished paper written between 6 April 1917 and 11 November 1918), Mead Papers Archive, Addenda, box 2, folder 29, 16 pp., Department of Special Collections, Regenstein Library, University of Chicago.

Mead, G. H. (1923) 'Scientific Method and the Moral Sciences', International Journal of Ethics 33: 229-47.

Mead, G. H. (1924) 'Review of The Domain of Natural Science by E. W. Hobson', Journal of Religion 4: 324-7.

Mead, G. H. (1925) 'The Genesis of the Self and Social Control', International Journal of Ethics 35: 251-77.

Mead, G. H. (1926) 'The Objective Reality of Perspectives', in E. S. Brightman (ed.) Proceedings of the Sixth International Congress of Philosophy. New York: Longmans Green.

Mead, G. H. (1927a) 'Social Psychology', unpublished manuscript (typescript of student notes by G. Shelburg, winter quarter), Mead Papers Archive, box 3, folder 4, 105 pp., Department of Special Collections, Regenstein Library, University of Chicago.

Mead, G. H. (1927b) 'Elementary Ethics', unpublished typescript of student notes on Mead's course, autumn quarter, Mead Papers Archive, box 7, folder 3 (pp. 1-118) and folder 4 (pp. 119-244), 244 pp., Department of Special Collections, Regenstein Library, University of Chicago.

Mead, G. H. (1930) 'Philanthropy from the Point of View of Ethics', in E. Faris, F. Laune and A. J. Todd (eds) Intelligent Philanthropy. Chicago, IL: University of Chicago Press. 
Mead, G. H. (1938) The Philosophy of the Act, ed. C. W. Morris et al. Chicago, IL: University of Chicago Press.

Mead, G. H. (1982) The Individual and the Social Self: Unpublished Work of George Herbert Mead, ed. D. L. Miller. Chicago, IL: Chicago University Press.

Mead, G. H. (1994) 'George Herbert Mead: An Unpublished Essay Review of Dewey's Human Nature and Conduct', Journal of the History of the Behavioral Sciences 30: 374-9.

Mead, G. H. (1997[1934]) Mind, Self, and Society from the Standpoint of a Social Behaviorist, ed. C. Morris. Chicago, IL: Chicago University Press.

Mead, G. H. (2002[1932]) The Philosophy of the Present, ed. A. E. Murphy. Amherst, NY: Prometheus Books.

Mead, G. H. (n.d.) 'On the Effects of Industrialization', unpublished manuscript, Mead Papers Archive, Addenda, box 3, folder 14, 40 pp., Department of Special Collections, Regenstein Library, University of Chicago.

Mead, G. H. (n.d.) 'How Can a Sense of Citizenship Be Secured?', unpublished manuscript, Mead Papers Archive, Addenda, box 2, folder 3, 11 pp., Department of Special Collections, Regenstein Library, University of Chicago.

Merton, R. (1967) 'On the History and Systematics of Sociological Theory', in R. Merton (ed.) On Theoretical Sociology. New York: Free Press.

Miller, D. L. (1973) George Herbert Mead: Self, Language and World. Chicago, IL: University of Chicago Press.

Silva, F. C. (2007) G. H. Mead. A Critical Introduction. Cambridge: Polity Press.

Thayer, H. (1968) Meaning and Action. A Critical History of Pragmatism. Indianapolis: Bobbs-Merrill.

\section{BIOGRAPHICAL NOTE}

FILIPE CARREIRA DA SILVA is a sociologist by training, with a MPhil in political theory from the University of Lisbon. After obtaining his doctorate from the Faculty of Social and Political Sciences, University of Cambridge, he conducted post-doctoral research at Harvard and Chicago with a Fulbright grant. Carreira da Silva is currently a full-time researcher at the Institute of Social Sciences, University of Lisbon and a senior member at Wolfson College, Cambridge.

Address: Instituto de Ciências Sociais, Universidade de Lisboa, Av. Prof. Anibal Bettencourt, 9, 1600-189 Lisboa, Portugal. [email: fcs23@ics.ul.pt] 